\title{
Pengembangan Produk Olahan Buah Mangrove Jenis Api-Api (Avicennia Spp) Di Kelompok Kreasi Mangrove Lestari Kelurahan Margomulyo Balikpapan
}

\author{
Patria Rahmawaty $^{1}$, Zulkifli $^{2}$, Nur Amaliah ${ }^{3}$, Hadi Hermansyah ${ }^{4}$, Yogiana Mulyani ${ }^{5}$ \\ patria.psikolog@gmail.com \\ Psikologi \\ Politeknik Negeri Balikpapan Kalimantan Timur
}

\begin{abstract}
Abstrak : Permasalahan yang dihadapi oleh Kelompok Kreasi Mangrove Lestari adalah tepung buah mangrove yang berwarna hitam diakibatkan proses pengolahan yang kurangtepatyaitupengeringan yang terlalu lama dan pada saat proses penggiling, masih secara sederhana, yaitu menggunakan blender. Sementara blender hanya dapat menampung kapasitas kecil dan ini akan menghambat proses mengolahan bahan baku menjadi produk olahan. Metode yang digunakan dalam memecahkan masalah Kelompok Kreasi Mangrove Lestari yaitu dengan sosialisasi proses pengolahan tepung buah mangrove yang sesuai standar, menyediakan alat penggiling tepung untuk mendapatkan tepung yang berkualitas baik, dan demostrasi pengolahan tepung buah mangrove menjadi snack dan cake. Berdasarkan hasil sosialisasi pengabdian masyarakat di Kelurahan Margomulyo dapat dikatan berhasil karena melihat antusias masyarakat Kelurahan Margomulyo yang mendapatkan ilmu terkait pengolahan tepung buah mangrove yang sesuai standar, mampu mengaplikasikan atau menggunakan alat penepung (disk mill), serta masyarakat mendapatkan resep standar dari produk swissroll tepung buah mangrove dan cimi-cimi tepung buah mangrove.
\end{abstract}

Kata Kunci : pengolahan, tepung mangrove, alat penepung

\section{ANALISIS SITUASI}

Hutan Mangrove Margomulyo di kelurahan Margomulyo kecamatan Balikpapan Barat di kota Balikpapan ini merupakan salah satu kawasan konservasi hutan yang digunakan sebagai tempat wisata. Fungsi utamanya adalah sebagai pelindung pantai dari pengaruh gelombang air laut. Hutan ini penuh dengan tanaman bakau diantaranya jenis api-api (Vicenna Spp), lindur (Bruguiera sp), nipah (Nypa Fruticans), piyai (A. aoreum). Tanaman bakau yang lebih dominan di Hutan Mangrove Margomulyo yaitu jenis api-api (Vicenna Spp), dimana masyarakat yang ada disana mengolah buah mangrove jenis api-api (Vicenna Spp) menjadi beberapa kuliner khas Balikpapan. Sebagai bahan makanan, buah api-api dapat dibuat keripikseperti kacang kapri dan rasanya gurih serta renyah seperti emping melinjo. Dari hasil penelitian menunjukkan komposisi hasil analisis dari bagian tanaman api-api menunjukkan bahwa bagian biji tanaman mengandung protein sebanyak 10,8\% dan karbohidrat sebanyak 
21,4\%, sehingga biji tanaman tersebut dapat dijadikan alternatif sebagai bahan pangan (Kusmana et al., 2009).

Kelompok Kreasi Mangrove Lestari merupakan kelompok yang sudah mengolah buah mangrove jenis api-api (Vicenna Spp) menjadi snack, kue bolu dan sirup. Karena melihat potensi komoditi mangrove yang ada di daerah tersebut sangat banyak, sehingga Kelompok Kreasi Mangrove Lestari mencoba menyimpan buah mangrove api-api dalam bentuk biji kering yang sudah melalui beberapa tahapan proses.

Buah mangrove membutuhkan beberapa proses terlebih dahulu sebelum dijadikan sebagai bahan makanan, seperti pengupasan kulit, pencucian dengan air mengalir, perendaman dengan air kapur atau abu gosok, perebusan, dan pengeringan serta kemudian dihancurkan/digiling. Pengolahan buah mangrove butuh kehati-hatian karena dalam buah mangrove tersebut terdapat tanin dan asam sianida (HCN) yang harus dihilangkan. Sebagai sumber pangan baru, analisa kandungan tanin dan asam sianida (HCN) merupakan indikator keamanan pangan. Karena tanin dan HCN dalam dosis tertentu bisa meracuni manusia.

Salah satu permasalahan yang dihadapi oleh kelompok Kreasi Mangrove Lestari ini adalah tepung buah mangrove yang berwarna hitam diakibatkan proses pengeringan yang terlalu lama dan pada saat proses penggiling, masih secara sederhana, yaitu menggunakan blender. Sementara blender hanya dapat menampung kapasitas kecil dan ini akan menghambat proses mengolahan bahan baku menjadi produk olahan. Berdasarkan dari hasil obersevasi tersebut dapat disimpulkan bahwa mereka membutuhkan proses pengolahan tepung yang sesuai standar dan alat penggiling khusus untuk buah mangrove hingga menjadi tepung sebagai bahan baku produk makanan.

\section{Permasalahan Mitra}

Setelah dilakukan kunjungan pada kelompok Kreasi Mangrove Lestari di kelurahan Margomulyo dapat disimpulkan bahwa standar tepung yang dihasilkan belum sesuai standar dikarenakan tepung yang dihasilkan berwarna hitam diakibatkan proses pengolahan yang kurang tepat. Selain pengolahan, fasilitas penunjang untuk mengolah buah mangrove tersebut masih sangat sederhana, yaitu menggunakan blender (alat bertenaga listrik untuk melumatkan buah, makanan dan lain-lain). Mengingat buah mangrove yang sudah melalui proses pengeringan menjadi sangat keras dan tidak dapat dihancurkan dengan alu atau lesung sehingga digunakan air pada saat penggilingan, proses tersebut menjadi kurang efektif karena melalui proses pengeringan kembali. 


\section{SOLUSI DAN TARGET}

\section{A. Solusi Yang Ditawarkan}

Adapun solusi yang ditawarkan, yaitu :

Buah mangrove jenis api-api (Avicennia spp) dapat diolah menjadi produk pangan yang berkualitas. Tepung buah mangrove merupakan produk antara yang dapat digunakan untuk berbagai macam kuliner/produk. Proses pembuatan tepung buah mangrove memerlukan perlakuan khusus karena terdapatnya senyawa tanin dan sianida yang memberikan rasa pahit pada produk. Pengolahan dengan menggunakan perendaman abu gosok atau abu dapur (soda ash) adalah salah satu cara yang dapat dilakukan karena abu gosok dapat menghambat laju oksidasi racun dan menetralkan asam yang bersifat karsinogenik pada bahan (Pembayun, 2000). Lanjut wirjatmadi (2005) menambahkan bahwa kadar sianida dapat dihilangkan dengan pencucian, perendaman, perebusan dan penjemuran. Oleh sebab itu, penurunan kandungan sianida pada produk tepung singkong dikarenakan terjadi penguapan sianida bebas saat proses pengeringan dengan menggunakan pengering pada suhu $70{ }^{\circ} \mathrm{C}$.

Untuk mendapatkan tepung buah mangrove yang baik melewati proses perebusan selama 30 menit lalu digupas kulit arinya. Selanjutnya dilakukan proses perendaman menggunakan abu dapur untuk menghilangkan racun dengan cara setiap hari air dengan abu dapur diganti pada jam yang sama selama 3 hari. Setelah air rendaman rasanya sudah tawar, selanjutnya bauh mangrove tersebut dikeringkan. Hasil yang sudah kering di haluskan lalu di ayak. Hasil ayakan (tepung) dapat diolah menjadi berbagai macam olahan makanan (Jailan dan Soamole, 2013).

\section{B. Target}

Adapunrencana target capaiantahunandapatdilihatpadatabel 2.1 di bawahini.

Tabel 2.1 Rencana Target Capaian Tahunan

\begin{tabular}{|c|c|c|c|c|}
\hline No. & \multicolumn{3}{|c|}{ Jenis Luaran } & $\begin{array}{c}\text { Indikator } \\
\text { Capaian }\end{array}$ \\
\hline \multirow{5}{*}{1} & \multirow{5}{*}{$\begin{array}{l}\text { Publikasi Ilmiah di } \\
\text { Jurnal }\end{array}$} & \multirow{3}{*}{ Nasional } & Internal Poltekba & Tidak Ada \\
\hline & & & $\begin{array}{l}\text { Eksternal Tidak } \\
\text { Terakreditasi }\end{array}$ & Tidak Ada \\
\hline & & & Eksternal Terakreditasi & Tidak Ada \\
\hline & & \multirow{2}{*}{ Internasional } & Tidak Terindeks & Tidak Ada \\
\hline & & & Terindeks & Tidak Ada \\
\hline \multirow{3}{*}{2} & \multirow{3}{*}{\multicolumn{2}{|c|}{ Pemakalah dalam pertemuan ilmiah }} & Lokal & Tidak Ada \\
\hline & & & Nasional & Tidak Ada \\
\hline & & & International & Tidak Ada \\
\hline
\end{tabular}




\begin{tabular}{|c|l|l|c|}
\cline { 2 - 3 } 3 & \multicolumn{2}{|l|}{ Buku Ajr (ISBN)/Bahan Ajar } & Tidak Ada \\
\hline 4 & \multicolumn{2}{|l}{ Model/Purarupa/Desain/Karya Seni/Rekayasa Sosial } & Tidak Ada \\
\hline 5 & Teknologi Tepat Guna & Tidak Ada \\
\hline 6 & \multicolumn{2}{|l|}{ Tingkat Kesiapan Teknologi (TKT) } & 7 \\
\hline \multirow{3}{*}{7} & \multirow{3}{*}{$\begin{array}{l}\text { Hak Atas Kekayaan Intelektual } \\
\text { (HKI) }\end{array}$} & Paten & Tidak Ada \\
\cline { 3 - 4 } & & Paten Sederhana & Tidak Ada \\
\cline { 3 - 4 } & & Hak Cipta & Tidak Ada \\
\cline { 3 - 4 } & Merek Dagang & Tidak Ada \\
\cline { 3 - 4 } & Desain Produk Industri & Tidak Ada \\
\hline
\end{tabular}

\section{PELAKSANAAN}

Metode pelaksanaan kegiatan ini adalah :

a. Penyediaan alat penggilingan

Kami akan menyediakan alat yang dapat menggiling atau menghancurkan buah mangrove yang sudah melalui proses pengeringan. Selama ini buah yang sudah kering sangat sulit untuk dihancurkan dengan menggunakan alu atau lesong. Padahal penghacuran buah tersebut untuk dapat menghasilkan tepung yang kelak akan menjadi salah satu bahan dasar pembuatan kue. Sebelum adanya mesin penggilingan, kelompok kreasi Mangrove Lestari menggunakan blender. Saat menghancurkan menggunkan blender maka harus diberi air lagi untuk mempermudah penggilingan hingga akhirnya dapat hancur dan digunakan sebagai bahan pembuat kue-kue. Hanya saja pemberian air dalam proses pembuatan tepung akan mengurangi kadar gizi yang terkandung dalam tepung.

b. Pada saat penyerahan alat penggiling buah mangrove tersebut kami akan memberikan penjeleskan cara pengolahan tepung yang sesuai standar dan penggunaan alat penggiling tepung (Disk Mill) kepada Kelompok Mangrove Lestari dan masyarakat sekitar wilayah kelompok tersebut untuk memotivasi masyarakat sekitar untuk melibatkan diri pada pengolahan buah mangrove yang kedepannya dapat menjadi sumber penghasilan di kawasan wisata tersebut.

c. Prosedur pengabdian, yaitu :

- Melakukan observasi di lapangan

- Menyiapakan alat dan bahan yang diperlukan

- Membawa alat penggilingan ke lokasi pengabdian 
- Memberikan pelatihan cara pengolahan tepung buah mangrove jenis api-api (Avicennia spp) dan penggunakan alat tersebut pada anggota Kreasi Mangrove Lestari Margomulyo.

- Demonstrasipembuatan cake dan snack daribahanbakutepungbuah mangrove.

- Menyerahkan alat penggilingan tepung tersebut pada kelompok Kreasi Mangrove Lestari Margomulyo.

d. Target Luaran

Memperolah tepung buah mangrove jenis api-api (Avicennia spp) yang berkualitas setelah melalui proses penggilingan dengan menggunakan alat yang sesuai dengan kebutuhan. Kelompok Kreasi Mangrove Lestari yang terdapat di Kelurahan Margomulyodapat membuat tepung buah mangrove dengan kualitas yang baik. Dengan adanya tepung buah mangrove dapat menjadikan solusi dalam kelangkaan bahan baku dari buah mangrove jenis Api-api (Avicennia spp). Tepung buah mangrove dapat dijadikan berbagai macam olahan makanan seperti cake, cracers, kue-kue tradisional lainnya.

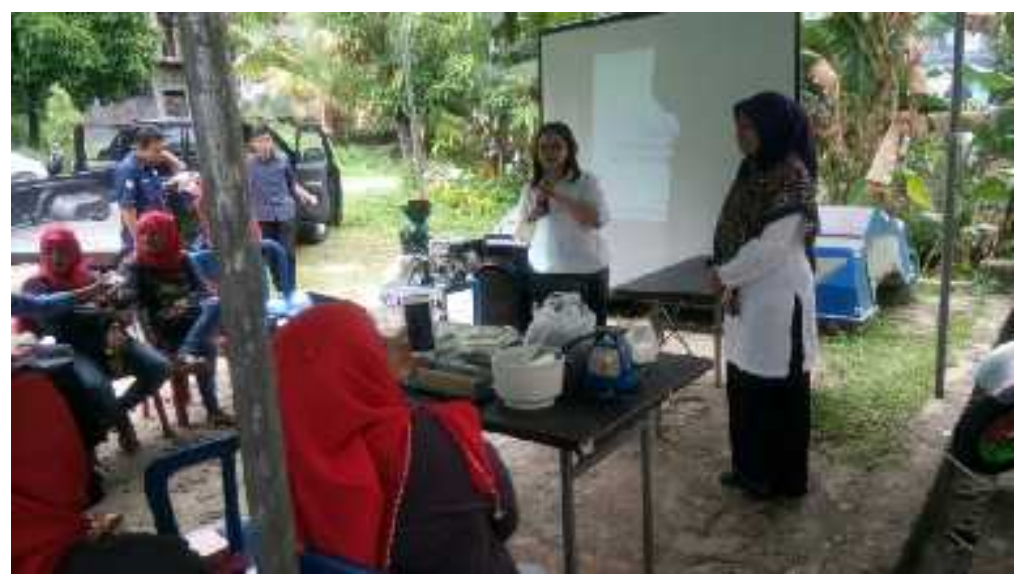

Gambar 1.Sambutan Ketua Pelaksana Pengabdian Masyarakat

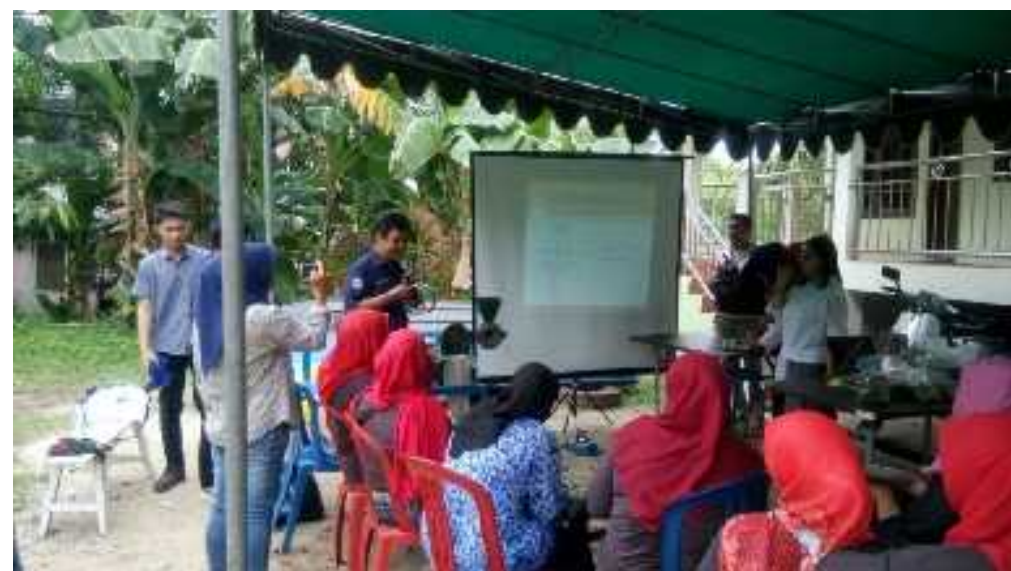

Gambar 2.Penjelasan Penggunaan Alat Penepung 


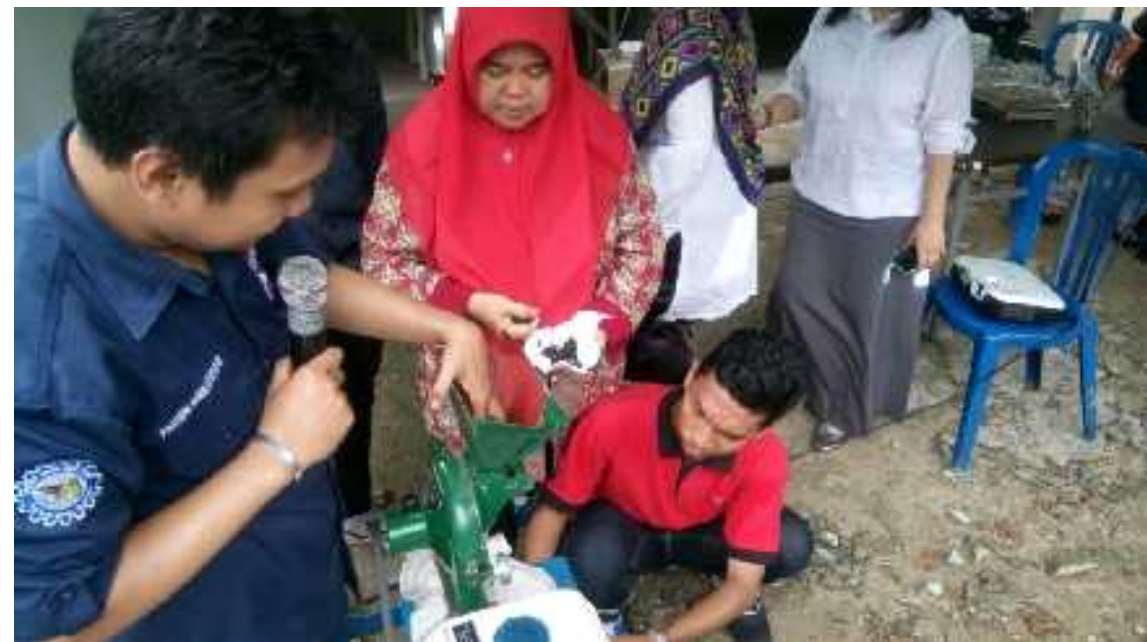

Gambar 3. Proses Penggilingan Buah Mangrove Melibatkan Masyarakat

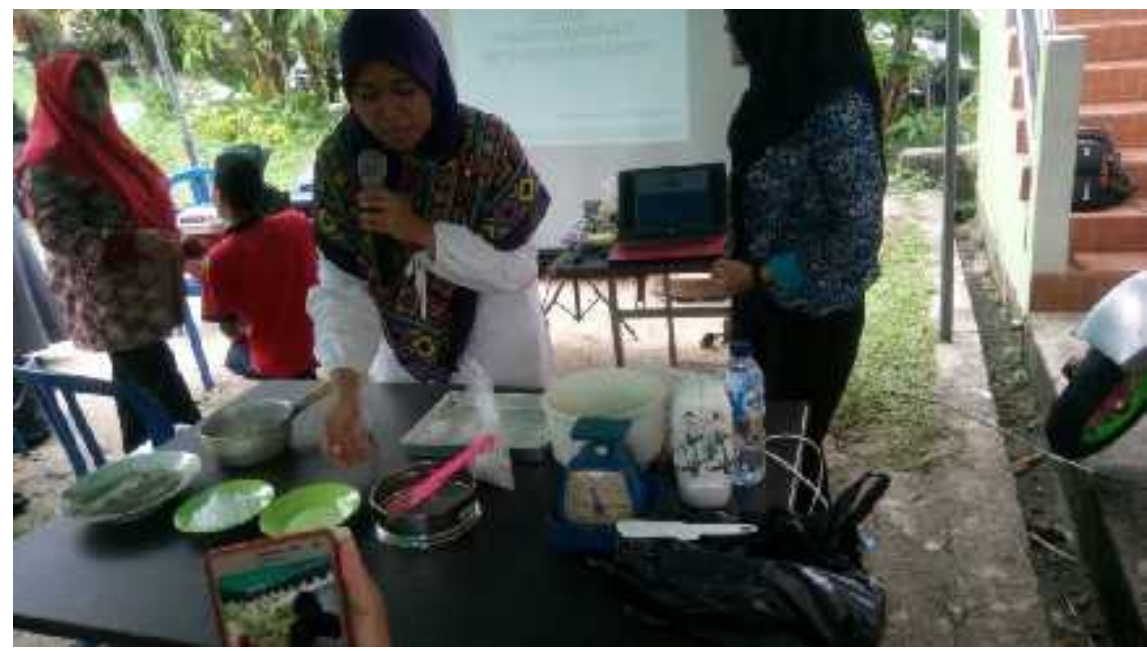

Gambar 4. Proses Pembuatan Produk Dari Tepung Buah Mangrove

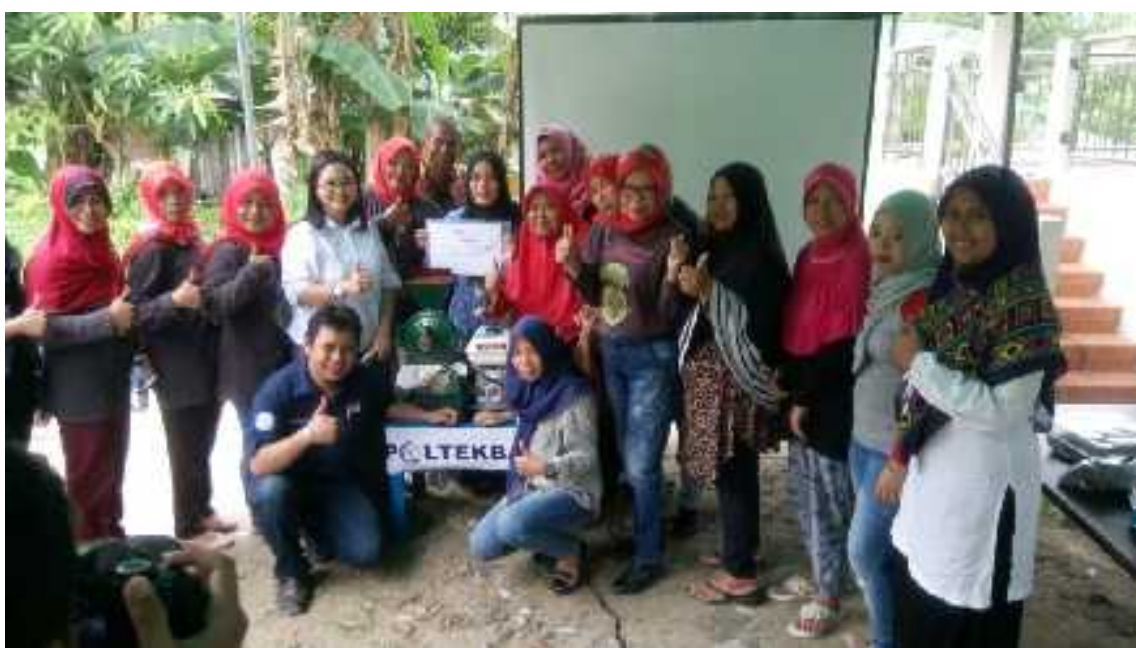

Gambar 5. Penyerahan dan Dokumentasi Bersama Masyarakat Margomulyo 


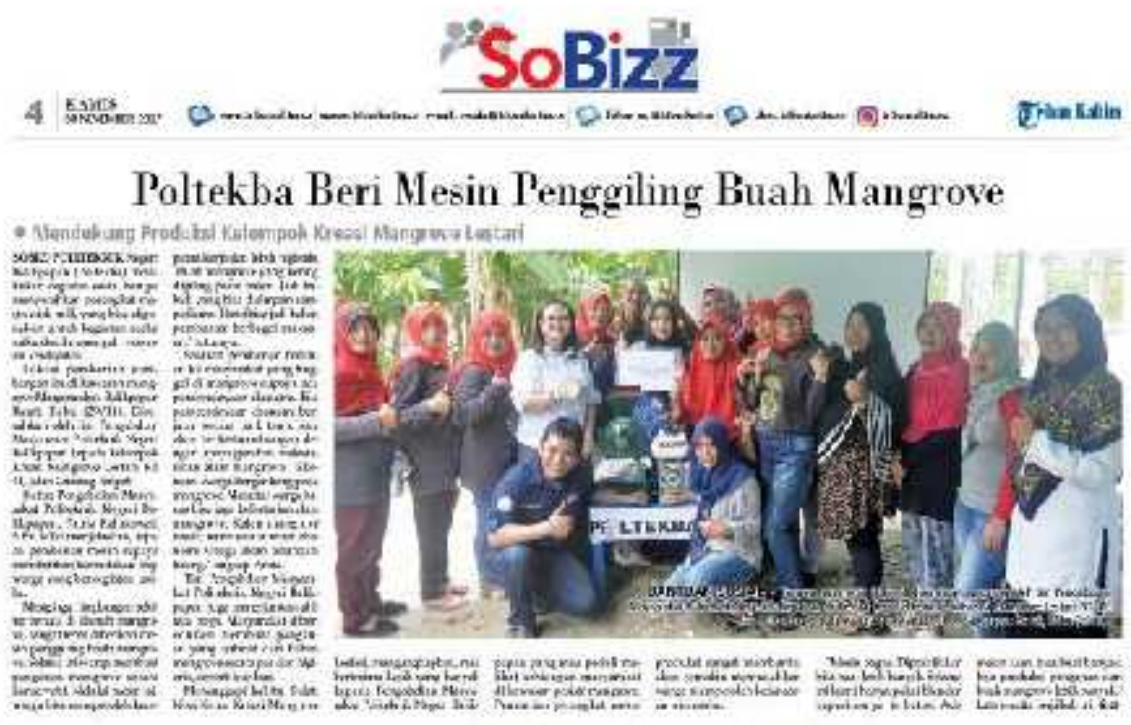

Gambar 6.Publikasi Media Cetak

\section{HASIL DAN LUARAN}

Hasil dan luaran kegiatan sosialisasi pengabdian masyarakat pada tanggal 29 November 2017 dihadiri Pegawai Kelurahan / mewakili, Masyarakat Kelurahan Margomulyo, dan Kelompok Kreasi Mangrove Lestari yang berjumlah 24 orang. Adapun hasil kegiatan sebagai berikut.

1. Anggota tim memberikan pengetahuan tentang cara pengolahan buah mangrove menjadi tepung buah mangrove yang berkualitas baik dengan cara buah api-api terlebih dahulu dikupas kulitnya lalu dilakukan perebusan selama 30 menit. Perebusan berfungsi untuk menghilangkan getah yang ada dipermukaan buah api-api. Setelah direbus, dilakukan perendaman dengan menggunakan kapur atau abu gosok (sebagai pengikat tanin) selama 3 hari. Tiap hari dilakukan pergantian air rendaman agar kualitas air rendaman tetap terjaga. Selanjutnya dilakukan pencucian agar kandungan sianida berkurang bahkan hilang dari buah. Dilakukan pengeringan selama $1-2$ hari hingga air yang ada dipermukaan mangrove hilang (tidak terlalu kering dan tidak berubah warna). Tahap akhir yaitu dilakukan penggilingan menggunakan alat penepung (disk mill) agar diperoleh ukuran tepung yang sesuai standar 80-90 mesh. Tepung siap untuk digunakan.

2. Melakukan demonstrasi pengolahan tepung buah mangrove menjadi cake (swissroll) dan snack (cimi-cimi) melibatkan masyarakat Kelurahan Margomulyo.

3. Menyerahkan alat penggilingan tepung (disk mill) kepada kelompok Kreasi Mangrove Lestari Margomulyo dengan didampingi pegawai kelurahan/mewakili 


\section{KESIMPULAN}

Setelah melakukan survey ke Hutan Mangrove Margomulyo di kelurahan Margomulyo kecamatan Balikpapan Barat di kota Balikpapan dan berkunjung kekelompok Kreasi Mangrove Lestari diperoleh kesimpulan bahwa masyarakat antusias mengikuti kegiatan sosialisasi pengabdian masyarakat dari awal hingga akhir kegiatan serta ikut berpartisipasi dalam aplikasi penggunaan alat penepung dan demonstrasi pengolahan produk dari tepung buah mangrove.

Dengan adanya kegiatan pengabdian masyarakat ini dapat meningkatkan kualitas produk dari kelompok Kreasi Mangrove Lestari dan menciptakan berbagai macam kuliner yang terbuat dari tepung buah mangrove. Dan dengan adanya bantuan alat penepung (disk mill) dapat lebih optimal dalam memproduksi tepung buah mangrove dan mencegah terjadinya kelangkaan bahan baku buah mangrove.

\section{DAFTAR RUJUKAN}

Halidah dan H. Kama. 2013. Penyebaran alami Avicennia marina (Forsk) Vierh dan Sonneratia Alba Smith pada Substrat pasir di Desa Tiwoho, Sulawesi Utara. Indonesian Rehabilitation Forest Journal, 1 (1) 51-58. Bogor.

Halidah. 2014. Avicennia marina (Forssk.) Vierh Jenis Mangrove YangKaya Manfaat. Vol. 11 No. 1, Mei 2014 : 37 - 44. Makassar.

Jailan S, I. Soamole. 2013. Pemanfaatan Buah Mangrove Sebagai Sumber Makanan Alternatif di Halmahera Barat, Maluku Utara. Vol 1, No. 2, hal 91-96. Ternate

Kusmana,C., A. Suryani, Y. Hartati dan P. Oktadiyani. 2009. Pemanfaatan jenis pohon Mangrove api-api (Avicennia spp.) sebagai bahan pangan dan Obat-obatan. IPB.

Priyono. A, Diah. I, Mohson, Lulut. S, Tengku. L, Hakim. 2010. Beragam Produk Olahan Berbahan Dasar Mangrove. Kesemat. Semarang

Wirjatmadi B. 2005. Pengaruh Beberapa Perlakuan Terhadap Penurunan Kadar HCN Pada Ubi Kayu (Maniholes culenta Crantz). Surabaya: Universitas Airlangga. 